\title{
Development of numerical model for predicting heat generation and temperatures in MSW landfills
}

\author{
James L. Hanson ${ }^{\mathrm{a}, *}$, Nazli Yeşiller ${ }^{\mathrm{b}}$, Michael T. Onnen ${ }^{\mathrm{c}}$, Wei-Lien Liu ${ }^{\mathrm{d}}$, Nicolas K. Oettle ${ }^{\mathrm{e}}$, \\ Janelle A. Marinos ${ }^{f}$ \\ ${ }^{a}$ Civil and Environmental Engineering Department, California Polytechnic State University, 1 Grand Ave., San Luis Obispo, CA 93407, USA \\ ${ }^{\mathrm{b}}$ Global Waste Research Institute, California Polytechnic State University, 1 Grand Ave., San Luis Obispo, CA 93407, USA \\ 'Civil and Environmental Engineering Department, California Polytechnic State University, San Luis Obispo, CA 93407, USA \\ ${ }^{\mathrm{d}}$ CTI Associates, 51331 Pontiac Trail, Wixom, MI 48393, USA \\ e University of California - Berkeley, 435 Davis Hall, Berkeley, CA 94720, USA \\ ${ }^{\mathrm{f}}$ Shannon and Wilson, Inc., 664 West Broadway, Glendale, CA 91204, USA
}

\begin{abstract}
A B S T R A C T
A numerical modeling approach has been developed for predicting temperatures in municipal solid waste landfills. Model formulation and details of boundary conditions are described. Model performance was evaluated using field data from a landfill in Michigan, USA. The numerical approach was based on finite element analysis incorporating transient conductive heat transfer. Heat generation functions representing decomposition of wastes were empirically developed and incorporated to the formulation. Thermal properties of materials were determined using experimental testing, field observations, and data reported in literature. The boundary conditions consisted of seasonal temperature cycles at the ground surface and constant temperatures at the far-field boundary. Heat generation functions were developed sequentially using varying degrees of conceptual complexity in modeling. First a step-function was developed to represent initial (aerobic) and residual (anaerobic) conditions. Second, an exponential growth-decay function was established. Third, the function was scaled for temperature dependency. Finally, an energyexpended function was developed to simulate heat generation with waste age as a function of temperature. Results are presented and compared to field data for the temperature-dependent growth-decay functions. The formulations developed can be used for prediction of temperatures within various components of landfill systems (liner, waste mass, cover, and surrounding subgrade), determination of frost depths, and determination of heat gain due to decomposition of wastes.
\end{abstract}

\section{Introduction}

Heat generation occurs in municipal solid waste (MSW) landfills due to decomposition of the organic fraction of the waste mass. Heat is a primary byproduct of MSW landfills similar to leachate and gas. The heat generated results in long-term elevated waste temperatures with respect to local air and ground temperatures. Elevated temperatures also are observed in bottom and cover liner systems due to the heat generation from contained wastes (Yeşiller et al., 2005, 2008).

Temperatures influence the engineering properties of geomaterials. Temperature extremes and thermal cycles affect the integrity and durability of earthen and geosynthetic components of waste containment barrier systems (Rowe, 2005). Temperatures also influence engineering response of wastes and decomposition of wastes (e.g., Hartz et al., 1982; Lamothe and Edgers, 1994). Determination and prediction of temperature conditions within landfill systems are required to evaluate the coupled geotechnical performance of these facilities. Fully coupled geotechnical and thermal numerical models represent the state-of-the-art in landfill analysis.

Heat generation potential for wastes was presented in the literature including values obtained by theoretical analyses of biochemical decomposition of wastes (Pirt, 1978; Rees, 1980; El Fadel et al., 1996; Zanetti et al., 1997; Yoshida and Rowe, 2003), values obtained by curve-fitting or back-calculation techniques applied to measured field data (Zanetti et al., 1997; Lefebvre et al., 2000; Hanson et al., 2008), and values for incineration of wastes (Tchobanoglous et al., 1993; SFOE, 2004; Davies, 2004; Gibbs, 2004). Heat generation due to biological processes was provided for varying phases of decomposition including aerobic phase, 
anaerobic phase, and total decomposition. Rates of heat generation were higher for the aerobic phase than the anaerobic phase (Yoshida and Rowe, 2003; McBean et al., 1995; Pirt, 1978). Heat generation values were reported per mass of glucose; per mole of gas (oxygen or methane) or organic matter (cellulose) converted; and per volume or mass of waste. Rates of heat production as well as absolute magnitudes of heat production were reported. A summary of heat generation values reported in literature in terms of equivalent heat generation rate per $\mathrm{m}^{3}$ of waste is provided in Yeşiller et al. (2005). The reported heat generation values cover a range extending more than 4 orders of magnitude that result from fundamental differences in formulation and the level of uncertainty in the estimated parameters.

Methods for modeling heat transfer in landfill systems also have been reported (El Fadel et al., 1996; Doll, 1997; Yoshida and Rowe, 2003; Southen and Rowe, 2005; Yeşiller et al., 2005; Hanson et al., 2008; Rowe and Hoor, 2009; Hoor and Rowe, 2011). Doll (1997) and Southen and Rowe (2005) used simplified constant elevated temperature conditions for modeling performance of liner systems without including temporal trends resulting from heat generation due to decomposition of wastes. El Fadel et al. (1996) developed a model for predicting heat transfer in landfills that included heat generation. A simplified function was used that was correlated only to estimated values of acetic acid generation rate and losses were assumed to be linearly related to heat generation. Yoshida and Rowe (2003) developed a model that included heat generation as a function of gas production rate. Rowe and Hoor (2009) and Hoor and Rowe (2011) used simplified constant elevated liner temperatures to represent overlying waste heat generation and conducted modeling of the liner system and subgrade to determine the duration to reach steady state conditions. Yeşiller et al. (2005) quantified heat generation as compared to unheated ambient conditions with limited heat transfer analysis. Hanson et al. (2008) provided methodology for determining heat generation using transient, nonlinear analyses.

The generally well established earth temperature theory provides a framework to model landfill heat transfer. Analytical solutions are available for thermal analysis of ground temperatures under seasonally cyclic ground surface temperature conditions incorporating amplitude decrement and phase lag with depth, frost depths, and layered systems (e.g., Carslaw and Jaeger, 1959; ORNL, 1981). Such analyses can be adopted for thermal analysis of landfills. Modeling the heat generation associated with MSW requires functions that can be incorporated using numerical techniques such as finite element analysis (FEA) or finite difference approach.

The objectives of this paper are to outline a methodology for thermal modeling of landfill systems and demonstrate model performance. Heat generation in wastes due to decomposition was modeled with variable heat generation rate functions for waste. Progressive conceptual development of the functions is presented in this paper. Material properties, model geometry and boundary conditions, heat generation rate functions, and overall methodology for model formulation are provided. The modeling approach described in this paper allows for establishing realistic thermal service conditions for landfill systems. Verification of model performance for a landfill site in Michigan, USA also is provided.

\section{Model formulation}

\subsection{Model framework}

Transient nonlinear analysis was used to simulate temporal variation of waste heat generation for representative analysis of landfill thermal regime. The analysis provided in Hanson et al. (2008) was expanded upon to incorporate temperature dependency of heat generation into modeling and provide verification with field data. The temperature field was determined as a function of time in the vertical direction. For this investigation, 1-D modeling was used to represent conditions at central regions (i.e., away from perimeter boundaries) of landfills. The heat transfer is described by

$k_{t} \frac{\partial T}{\partial^{2} x}+\dot{q}=C \frac{\partial T}{\partial t}$

where $k_{t}$ is the thermal conductivity $(\mathrm{W} / \mathrm{m} \mathrm{K}), T$ the temperature $\left({ }^{\circ} \mathrm{C}\right), x$ the distance $(\mathrm{m}), \dot{q}$ the rate of heat generation $\left(\mathrm{W} / \mathrm{m}^{3}\right), C$ the volumetric heat capacity $\left(\mathrm{kJ} / \mathrm{m}^{3} \mathrm{~K}\right)$ [equivalent to density times mass heat capacity], and $t$ is the time (s).

The primary matrices for heat conduction are a conductivity matrix, analogous to a stiffness matrix in a structural analysis, and a heat capacity matrix, analogous to a mass matrix. The elemental stiffness matrices, nodal degrees of freedom, and nodal loads can be summed into global matrices, resulting in a final equation, which can be used to solve for all unknown nodal degrees of freedom (Cook et al., 2002),

$[K]\{D\}=\{R\}$

where $K$ is the global stiffness matrix (thermal conductivity), $D$ the nodal degrees of freedom vector (temperature), $R$ is the nodal load vector (heat flux).

The analysis was formulated using finite element analysis (FEA) with a commercially available modeling program (ABAQUS version $6.10-2)$. A series of simulations was conducted with varying degrees of mesh refinement using element sizes ranging from $0.1 \mathrm{~m}$ to $6 \mathrm{~m}$. An element size of $0.5 \mathrm{~m}$ was selected based on a relative error analysis conducted using these simulations (Cook et al., 2002). The time step for transient analysis is in part controlled by element size, and the time step was established as 1 day for most analyses.

\subsection{Material properties}

For heat transfer analysis of landfills, material properties were required for the cover, waste, bottom liner, and subgrade. In particular, unit weight, thermal conductivity, and heat capacity were required. The heat transfer analysis provided herein was conducted using data from a MSW landfill located in Michigan, USA. The site has been extensively instrumented and characterized for thermal response (e.g., Yeşiller et al., 2005; Hanson et al., 2010). Operational conditions for the site included: design waste placement area $=65$ ha, average waste intake rate $=965,000 \mathrm{t} / \mathrm{year}$, and waste placement rate $=24 \mathrm{~m} /$ year. The site began accepting waste in 1984. The site is located in a cool temperate zone, with humid continental temperate climate (Landsberg et al., 1966). Climatic details included: average daily temperature $=14.7^{\circ} \mathrm{C}$, annual normal precipitation $=835 \mathrm{~mm}$, annual normal snowfall $=1046 \mathrm{~mm}$, and mean annual earth temperature $=12.3^{\circ} \mathrm{C}$. Additional details regarding operational and climatic conditions at the site were provided in Yeşiller et al. (2005).

Weight-volume relations of the soils were determined using site records. Fractions of constituent components of the wastes were obtained from U.S. EPA (2003) for disposed wastes. The U.S. EPA data provided generalized values for waste composition for numerical analysis as detailed characterization of waste composition at the study site was beyond the scope of the investigation. The waste components, fractions, and mass heat capacities for individual components are provided in Table 1. Material properties required for thermal analysis are provided in Table 2. Unit weight $(\gamma)$ was determined using operational records for earthen barrier materials, wastes, and native subgrade soils at the site. Thermal conductivity $\left(k_{t}\right)$ was determined using laboratory and field thermal conductivity probe experiments (Hanson et al., 2000) and 
Table 1

Waste Composition.

\begin{tabular}{lcc}
\hline Waste component & Percent of total weight (\%) & Mass heat capacity $(\mathrm{J} / \mathrm{kg} \mathrm{K})$ \\
\hline Paper & 27.1 & 1260 \\
Glass & 4.1 & 1160 \\
Ferrous metal & 4.5 & 630 \\
Aluminum & 1.1 & 880 \\
Nonferrous metal & 0.5 & 934 \\
Plastics & 8.7 & 1800 \\
Rubber and leather & 2.2 & 1590 \\
Textiles & 3.5 & 1310 \\
Wood & 4.5 & 1360 \\
Food wastes & 9.0 & 1715 \\
Yard trimmings & 9.3 & 1360 \\
Inorganic wastes & 1.2 & 1842 \\
Other & 1.4 & 850 \\
Water & 23.1 & 4190 \\
\hline
\end{tabular}

Data from Yoshida et al. (1999), Miller and Clesceri (2003), and U.S. EPA (2003).

Table 2

Material properties for analyses.

\begin{tabular}{ll}
\hline Property & Value \\
\hline$\gamma_{\text {waste }}\left(\mathrm{kN} / \mathrm{m}^{3}\right)$ & 9.8 \\
$\left.k_{t \text {-waste }}(\mathrm{W} / \mathrm{m} \mathrm{K}) \mathrm{K} / \mathrm{m}^{3} \mathrm{~K}\right)$ & 1.0 \\
$C_{\text {waste }}\left(\mathrm{kJ} \mathrm{m}^{2} / \mathrm{s}\right)$ & 2000 \\
$\alpha_{\text {waste }}\left(\mathrm{m}^{3}\right)$ & $5.0 \times 10^{-7}$ \\
$\gamma_{\text {soil }}\left(\mathrm{kN} / \mathrm{m}^{3}\right)^{\mathrm{a}}$ & 20.5 \\
$k_{\text {t-soil }}\left(\mathrm{W} / \mathrm{m} \mathrm{K}^{\mathrm{a}}\right.$ & 2.5 \\
$C_{\text {soil }}\left(\mathrm{kJ} / \mathrm{m}^{3} \mathrm{~K}\right)^{\mathrm{a}}$ & 2800 \\
$\alpha_{\text {soil }}\left(\mathrm{m}^{2} / \mathrm{s}\right)^{\mathrm{a}}$ & $9.0 \times 10^{-7}$ \\
\hline
\end{tabular}

a soil represents subgrade, bottom liner system, and cover system.

using data from literature (e.g., Andersland and Ladanyi, 2003). Volumetric heat capacity $(C)$ was calculated by summing heat capacity of individual components of the materials to provide a weighted average. Thermal diffusivity $(\alpha)$ was calculated as the quotient of thermal conductivity and volumetric heat capacity. In general, both $k_{t}$ and $C$ (for wastes and soils) increase with increasing unit weight and moisture content. Thermal properties for three other landfills located in different climatic regions were presented by Hanson et al. (2008), which can be used for heat transfer analysis at landfills in different settings.

\subsection{Boundary conditions}

Boundary conditions required in modeling landfill heat transfer consisted of far field boundary at depth and the ground surface boundary. The far field boundary was established $75 \mathrm{~m}$ below the bottom liner. This depth was determined by analyzing the temperature response of different model geometries using increasingly greater depths. Simulations were conducted using variable depths below a liner system maintained at a constant temperature of $30^{\circ} \mathrm{C}$, consistent with long-term stable field measurements in a liner system (Hanson et al., 2010). Simulations were conducted for depths below bottom liner system ranging from 10 to $200 \mathrm{~m}$ for 30-year simulation periods. The $75 \mathrm{~m}$ distance from the liner to the bottom boundary was determined as the first depth at which the differential in model temperatures between the simulation for $200 \mathrm{~m}$ boundary and the nearer boundary was less than $0.1^{\circ} \mathrm{C}$. The far field boundary was fixed at the mean annual earth temperature. The mean annual earth temperature was obtained using field measurements from control locations at a distance from the waste mass in combination with data from literature for groundwater temperatures (e.g., ORNL, 1981).
Table 3

Summary of boundary conditions used in the model.

\begin{tabular}{ll}
\hline Parameter & Value \\
\hline Mean soil temperature, $T_{m}\left({ }^{\circ} \mathrm{C}\right)$ & 12.3 \\
Amplitude for soil temperatures, $A_{s}\left({ }^{\circ} \mathrm{C}\right)$ & 17.3 \\
Thawing $n$-factor (soil) & 1.23 \\
Freezing $n$-factor (soil) & 0.91 \\
Mean cover temperature, $T_{m}\left({ }^{\circ} \mathrm{C}\right)$ & 14.6 \\
Amplitude for cover temperatures, $A_{s}\left({ }^{\circ} \mathrm{C}\right)$ & 16.6 \\
Thawing $n$-factor (waste) & 1.27 \\
Freezing $n$-factor (waste) & 0.56 \\
\hline
\end{tabular}

The ground surface boundary for landfills is highly complicated to define due to the coupled influence of climatological effects (wind, precipitation, moisture evaporation, solar radiation), surface conditions (ground material type, snow cover), and heat gain from decomposition of underlying wastes. A common approach to obtain ground surface temperatures is to modify air temperatures to account for radiation absorption and emission effects using ground surface freezing and thawing $n$-factors (Andersland and Ladanyi, 2003). Freezing or thawing indices represent the area bound by the temperature-time curve and the $0{ }^{\circ} \mathrm{C}$ baseline (area below $0{ }^{\circ} \mathrm{C}$ for freezing, area above $0{ }^{\circ} \mathrm{C}$ for thawing). The $n$-factors are determined as the quotient of paired surface and air indices for freeze or thaw. These factors are typically applied on a seasonal basis to provide idealized sinusoidal annual ground surface temperature fluctuations. Surface $n$-factors are affected by climatic and ground surface conditions.

Well established surface $n$-factors generally have not been reported for landfill conditions. For model formulation, ground surface temperatures were determined based on an analysis of ground surface and near-surface temperatures measured at landfill sites using data presented in Yeşiller et al. (2008). Measured ground surface temperatures were highly variable due to surface weather effects and measurement frequency. Therefore, measured near surface temperature extremes (i.e., maximum and minimum ground temperatures obtained from sensors placed at depths ranging from 0.15 to $2 \mathrm{~m}$ ) were extrapolated upward to obtain an idealized ground surface temperature function at the test site (Oettle et al. 2008). The resulting idealized sinusoidal ground surface temperatures were used with measured air temperatures to back-calculate $n$-factors for the site by applying conventional 30-year definition (Andersland and Ladanyi, 2003). These $n$-factors were applied for converting air temperatures to ground surface temperatures for landfill conditions at the test site. Surface $n$-factors for landfills in different climatic regions are provided in Yeşiller et al. (2008), which can be used for heat transfer analysis of landfills in different settings. For all ground surface temperature waves, a phase lag of $\pi / 4$ was applied (Carslaw and Jaeger, 1959), such that the warmest surface temperature occurred 45.6 days after the summer solstice. A summary of the parameters used for boundary conditions is presented in Table 3 .

\subsection{Geometry}

The model development accounted for containment system geometry progression with time (an excavated landfill cell below grade, placement of bottom liner, waste filling, and installation of landfill cover). Thermal properties corresponding to the different layers presented in Table 2 were used. Chronologically, first the excavated landfill cell was modeled. The initial temperature of native subgrade soil (from bottom liner system to the far-field boundary) was uniformly set to the mean annual earth temperature. The model was then allowed to run under application of the idealized ground surface temperature function for the soil. The 
surface temperatures were applied until long-term annual temperature cycle stasis of the subgrade was obtained. Approximately 7 years of simulation were required to reach this condition. Second, the placement of the bottom liner ( $1 \mathrm{~m}$ thick including soil and geosynthetic components) was modeled. Third, waste filling was modeled. The waste placement sequences were obtained from site records including annual aerial fly-over surveys, land-based topographic measurements, and detailed waste placement records. Waste placement was modeled using individual compacted lifts of approximately 3-5 m thickness. Progression of waste placement was modeled using application of a surface temperature function (accounting for seasonal variability) to locations of increasing vertical elevation with time. The model geometry including the application of seasonal temperature fluctuation at an intermediateheight waste surface is presented in Fig. 1. The waste was placed at a temperature equal to average daily air temperature on the day of placement based on field measurements of temperatures of as-delivered wastes. Next, the idealized seasonal surface temperature wave was applied to the waste surface. Heat generation functions were applied sequentially with waste placement to the entire column of waste (i.e., by keeping track of the wastes placed at various elevations and corresponding starting times for initiation of heat generation). Fourth, the installation of cover system (either interim or final cover) was modeled. Based on thickness obtained from site records, a $1 \mathrm{~m}$ thick cover system representative of soil and geosynthetics was used. The initial temperature of the cover materials was assumed to be equal to the ground surface temperature on the day of installation. Then, the idealized seasonal surface temperature wave was then applied to the cover to simulate temperatures over the long term.

\subsection{Heat generation rate functions}

The heat generation rate functions were developed empirically, whereas the general heat transfer and associated boundary conditions were mechanistic. The functions varied with waste age wherein heat generation rate was typically relatively high for young wastes and low for old wastes (Hanson et al., 2008; Liu, 2007). The heat generation rate functions were formulated to account for net heat gain due to decomposition under normal landfill operations. The functions therefore accounted for thermal losses such as convective heat flow due to leachate migration and removal. Heat generation functions were developed in increasing degrees of complexity including a step function model, an exponential growth-decay model, a temperature-dependent exponential growth-decay model, and a coupled temperature/waste-age dependent (i.e., energy expended) model. The model parameters

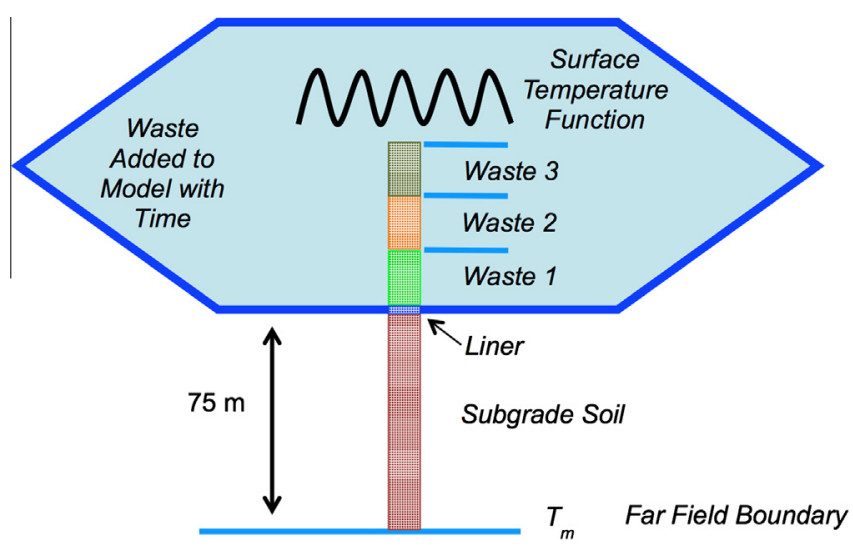

Fig. 1. Model geometry. for the heat generation functions were established for the test site using longstanding data that have been obtained from this landfill since 1999. Preliminary versions of the step and exponential growth-decay models were presented in Hanson et al. (2008). These models are reviewed herein for completeness of the presentation of the numerical analysis methodology.

Initially, a step-function was used to model heat generation rate in wastes due to aerobic and anaerobic decomposition (Hanson et al., 2008). In this formulation it was assumed that the initial aerobic phase occurred during the first 4 months subsequent to placement of waste. Then, the waste entered the anaerobic phase and remained under this condition for the balance of the analysis. The 4-month period was selected for the aerobic phase based on the analysis of gas concentration data from field measurements at the study site (Hanson et al., 2005; Liu, 2007). The resulting values for aerobic and anaerobic heat generation rates at the landfill were 11.3 and $0.38 \mathrm{~W} / \mathrm{m}^{3}$, respectively.

Next, a more complex exponential growth and decay function (Eq. (3)) was used for modeling heat generation (adapted from Hanson et al., 2008). The format of Eq. (3) was developed independently to provide more realistic representation of waste decomposition than a step function. The function resulted in growth of heat generation rate to a peak value followed by an exponential decay (Fig. 2). The constants $\left(A, B_{t}, C_{t}\right.$, and $\left.D\right)$ control the peak value, the shape of the peak, and the rate of decay.

$H=A\left(\frac{t}{B_{t}+t}\right)\left(\frac{C_{t}}{C_{t}+t}\right) e^{-\sqrt{\frac{t}{D}}}$

where $H$ is the heat generation rate $\left(\mathrm{W} / \mathrm{m}^{3}\right), t$ the time (day), $A$ the peak heat generation rate factor $\left(\mathrm{W} / \mathrm{m}^{3}\right), B_{t}, C_{t}$ the shape factors (day), and $D$ is the decay rate factor (day).

The exponential growth and decay heat generation rate function (Fig. 2) was then scaled for temperature dependence of heat generation. Peak heat generation, determined directly from Eq. (3), was used when the waste temperatures were in the range of $30-50{ }^{\circ} \mathrm{C}$. For waste temperatures above (extending from $50{ }^{\circ} \mathrm{C}$ up to $80^{\circ} \mathrm{C}$ ) and below (extending from $30^{\circ} \mathrm{C}$ down to $0{ }^{\circ} \mathrm{C}$ ) this range, a linear ramped function was used. For waste temperatures below $0{ }^{\circ} \mathrm{C}$ and above $80^{\circ} \mathrm{C}$, zero heat generation was prescribed. The result of the temperature dependency is a dual-ramped function as presented in Fig. 3. When combined with the exponential growth and decay heat generation rate function, a 3-D plot results as presented in Fig. 4. Parameters were determined using best fit nonlinear regressions with field data from the landfill.

Finally, energy-expended based heat generation functions were developed conceptually to provide broader application of the modeling methodology and avoid potential numerical inconsistencies.

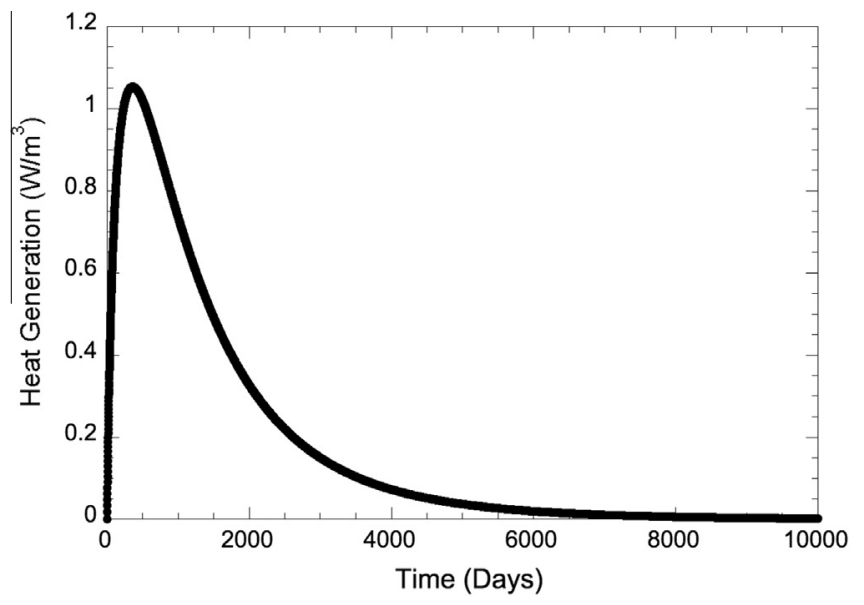

Fig. 2. Exponential growth and decay heat generation function. 
The basic framework for the energy-expended based functions was the time-based exponential growth and decay heat generation rate functions. Two major modifications were made to this formulation to establish temperature-dependency of the heat generation functions. First, the functions were translated from a time domain to an energy-expended domain by integrating the heat generation rate versus time function with time using piecewise integration through equation solver software. The total area under the time based heat generation rate function is equivalent to the $x$-intercept on the energy expended function. The basic 2-D energy expended heat generation rate function is presented in Fig. 5. Second, a similar conversion that was used for the time-based function to provide temperature dependency using dual-ramped functions is made to broaden model applicability. With these modifications, instead of monitoring time (i.e., waste age) to determine incremental heat generation rate, the accumulated energy expended up to a specific time step is monitored. Such a translation provides for a function in which each progressive time step results in monotonic progress along the function surface.

Expended energy formulation was developed to progress through variable scenarios of temperature and heat generation response without numerical inconsistencies. Without such a change to the formulations, an invalid heat generation response is possible (requiring going back in time to reach higher levels of heat generation associated with optimal temperature conditions). The timebased temperature-dependent (Fig. 4) heat generation rate function may cause numerical inconsistencies with expected behavior for a variety of situations as the model is applied to different climatic regions.

An example of a case where inconsistencies would arise is a cold climate for which heat generation does not initiate for several years and waste remains at relatively low temperatures for extended periods of time (Hanson et al., 2006). In a simulation using time domain heat generation rate function, the peak heat generation rate would potentially be bypassed as time is continually progressing forward. To capture peak heat generation rate, the model would have to revert back in time, which cannot be numerically accomplished in an efficient manner. By converting to an energyexpended (in place of time) domain, the waste heat generation for this same example remains at low temperature and low heat generation rates during the early (i.e., cold) years of the simulation. As heat generation occurs, the model progresses forward with expended energy and it becomes possible to properly model the heat generation in the system with time.

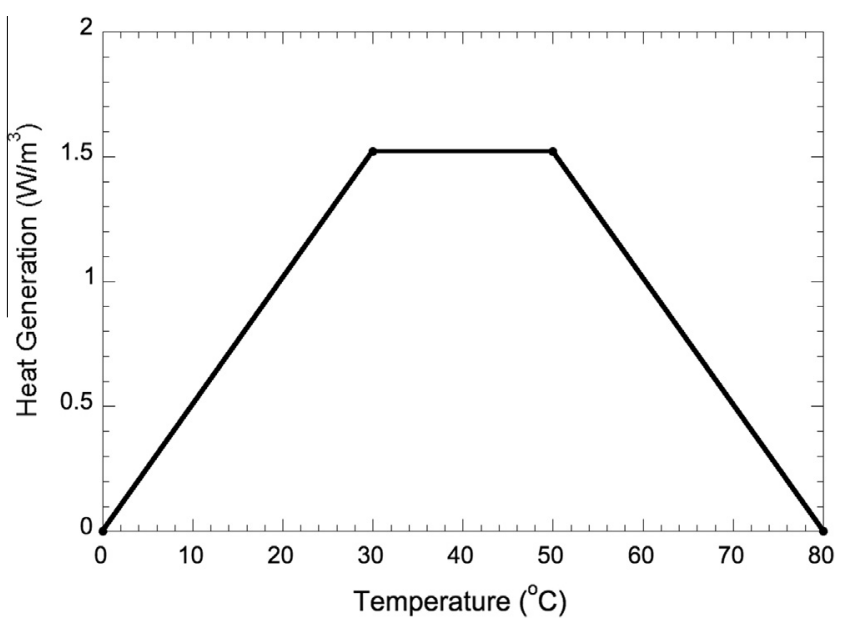

Fig. 3. Dual ramped scaling function.

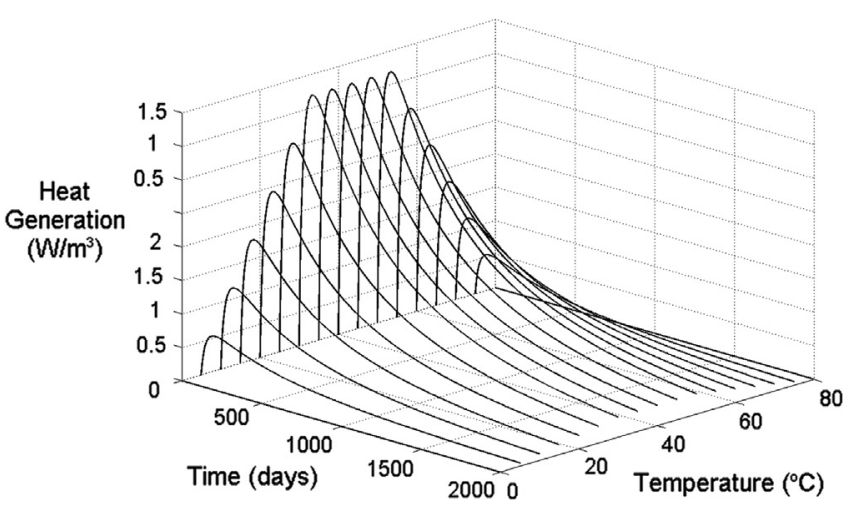

Fig. 4. Temperature dependent heat generation function.

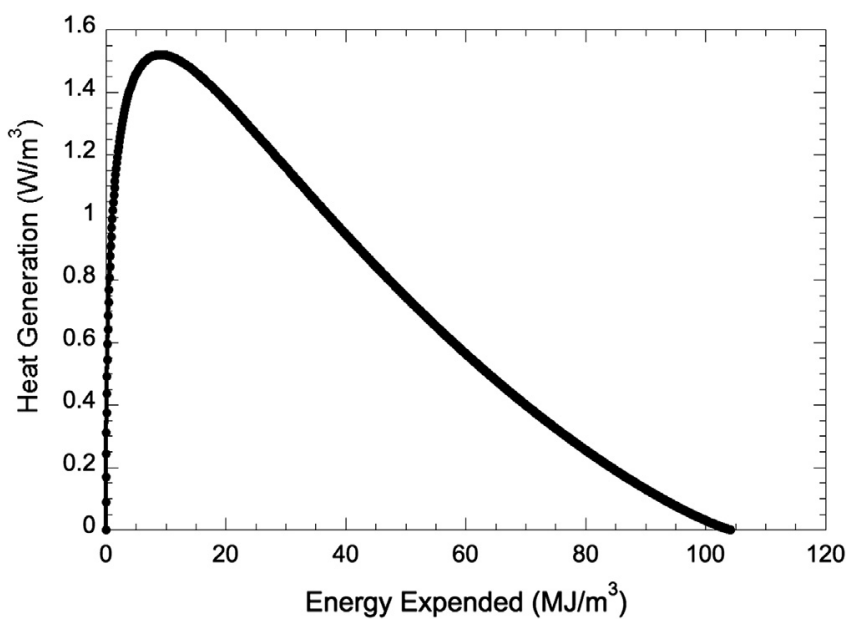

Fig. 5. Energy-expended-based heat generation function.

\section{Model validation}

Modeling was conducted using the material properties, geometries, and boundary conditions described above. Results are provided for modeling conducted using the dual-ramped, time-based heat generation function herein (i.e., Fig. 4). A summary of results for the step and growth-decay functions were provided elsewhere (Hanson et al., 2008). The prevailing operational and climatic conditions at the Michigan site did not warrant the use of energy expended function (this function will be used for a cold regions site in further modeling). The dual ramped heat generation functions were developed using data from Cells D and B at the landfill. These cells represent dissimilar conditions at the site and demonstrate variability in heat generation that may result at a given site. Cell D contained predominantly curbside waste (i.e., conventional residential MSW) whereas Cell B contained a higher ratio of construction and demolition waste. No leachate recirculation was applied at Cell D whereas leachate recirculation was applied regularly during early years at Cell B (completed prior to monitoring period presented herein).

Temperature data were collected in Cell D since the onset of waste placement. Temperature sensors were placed in horizontal arrays in trenches within the waste mass as the elevation of the waste mass increased from $0 \mathrm{~m}$ to $31.5 \mathrm{~m}$ (as described in Hanson et al. (2010)). Five total sensors were used to monitor the vertical profile of waste temperatures near the center of the cell. For Cell $\mathrm{B}$, temperature sensors were placed 5 years after initial waste placement as a vertical array extending $13 \mathrm{~m}$ deep into the waste mass with a total thickness of $33 \mathrm{~m}$. Thirteen total sensors (with 
Table 4

Summary of dual-ramped exponential growth and decay heat generation functions used in the model.

\begin{tabular}{lll}
\hline Parameter & Cell D & Cell B \\
\hline Peak heat generation rate value $\left(\mathrm{W} / \mathrm{m}^{3}\right)$ & 1.52 & 1.16 \\
Time for peak value $($ days $)$ & 87 & 360 \\
Total energy expended $\left(\mathrm{MJ} / \mathrm{m}^{3}\right)$ & 104 & 174 \\
$A$ & 4.88 & 104.5 \\
$B_{t}$ & 50 & 5000 \\
$C_{t}$ & 5000 & 5000 \\
$D$ & 180 & 120 \\
\hline
\end{tabular}

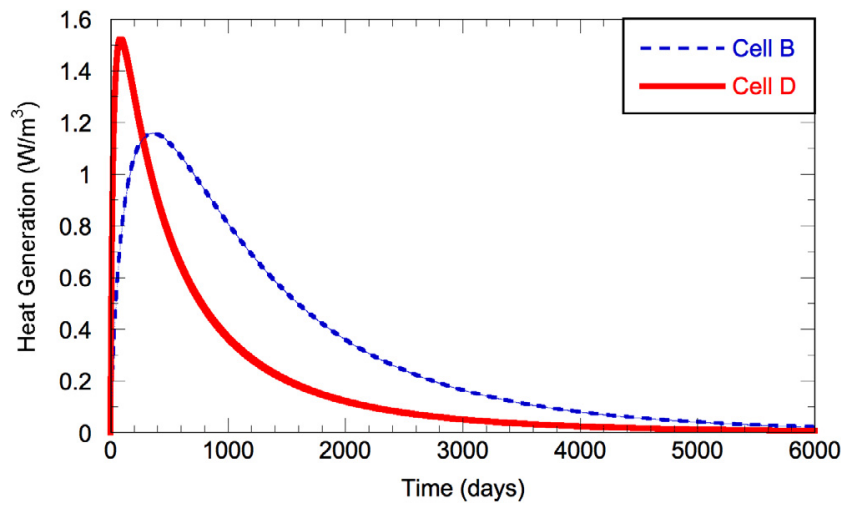

Fig. 6. Resulting heat generation functions for Cells D and B.

vertical spacing of $1 \mathrm{~m}$ ) were used to monitor the vertical profile of waste temperatures at Cell B. Data were measured approximately weekly for the entire study period at both Cells D and B.

A timeframe of 5 years of monitoring (corresponding to $0-5$ years since initial waste placement) was used for the model validation at Cell D and a timeframe of 4 years of monitoring (corresponding to 5-9 years since initial waste placement) was used for the model validation at Cell B. Parameters for the dual-ramped time-based heat generation functions were established using best-fit nonlinear regression analysis of field data. The resulting parameters for Cells D and B are presented in Table 4. The resulting time-based heat generation rate functions are presented in Fig. 6. The different shapes of heat generation functions used were reflective of operational conditions (i.e., waste composition and presence of leachate recirculation) for the cells. As site records were not complete in terms of waste composition and quantities of liquids on a cell-by-cell basis, the waste composition and presence of leachate recirculation were built into the empirically developed heat generation rate functions rather than modeled directly mechanistically.

The results of the model development and model validation analyses are provided in Figs. 7 (newly placed wastes, Cell D) and Fig. 8 (relatively older wastes, Cell B). The lengths provided on the plots after cell designation refer to depth below ground surface for a given temperature sensor. In general, the trends in modeled and measured temperatures versus time were similar for the range of waste age and waste depth used for comparison. Damping of seasonal temperature variations with depth, phase lag with depth, and onset and presence of heat gain due to waste decomposition were captured by the modeling. The modeled temperatures were generally within $\pm 5{ }^{\circ} \mathrm{C}$ of measured temperatures throughout the entire depth of the landfill with the majority of the data within $\pm 2{ }^{\circ} \mathrm{C}$ of measured temperatures. Model performance was generally better at greater depths, with most pronounced variation from the field data observed at relatively shallow depths.

Model results with depth are presented in Fig. 9. Bold lines represent the limiting temperature envelope (i.e., maximum and
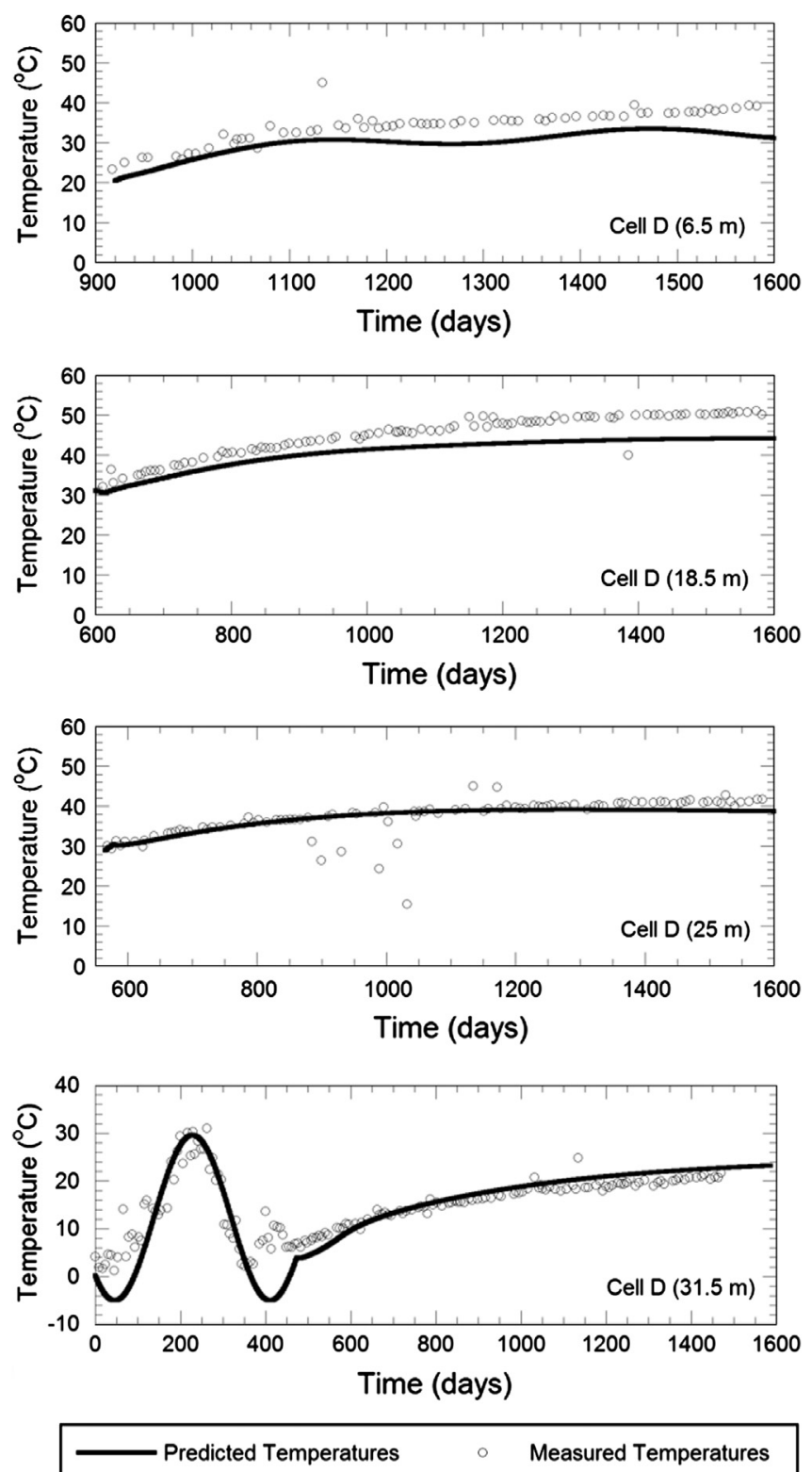

Fig. 7. Model performance for model validation in new wastes at Cell D.

minimum temperatures at given depths) obtained from the modeling. Fine lines represent isochrones (i.e., temperature profile with depth for a given date) for measured field temperatures. Model temperatures with depth at Cell D had higher localized variability than those for Cell B. This is due to the period used for comparison to field data. The high variability in waste surface conditions during placement resulted in high variability in the field data obtained from Cell D. Data collection and simulation durations at Cell B represented conditions subsequent to waste placement (i.e., waste height reaching final elevation). Therefore, at Cell B, higher variability in data was present near the permanent ground surface (i.e., top of waste mass) than at depth where relatively stable elevated temperatures had been reached. Overall, the main trends of temperature variation with depth including high temperature variation near the surface, elevated stable temperatures with less variability at central depths, and somewhat elevated stable temperatures at great depth were captured by the model. An analysis was conducted to determine the fraction of field data contained within the limiting temperature envelope obtained from the modeling. For Cell D, $56 \%$ of the field data was contained within 

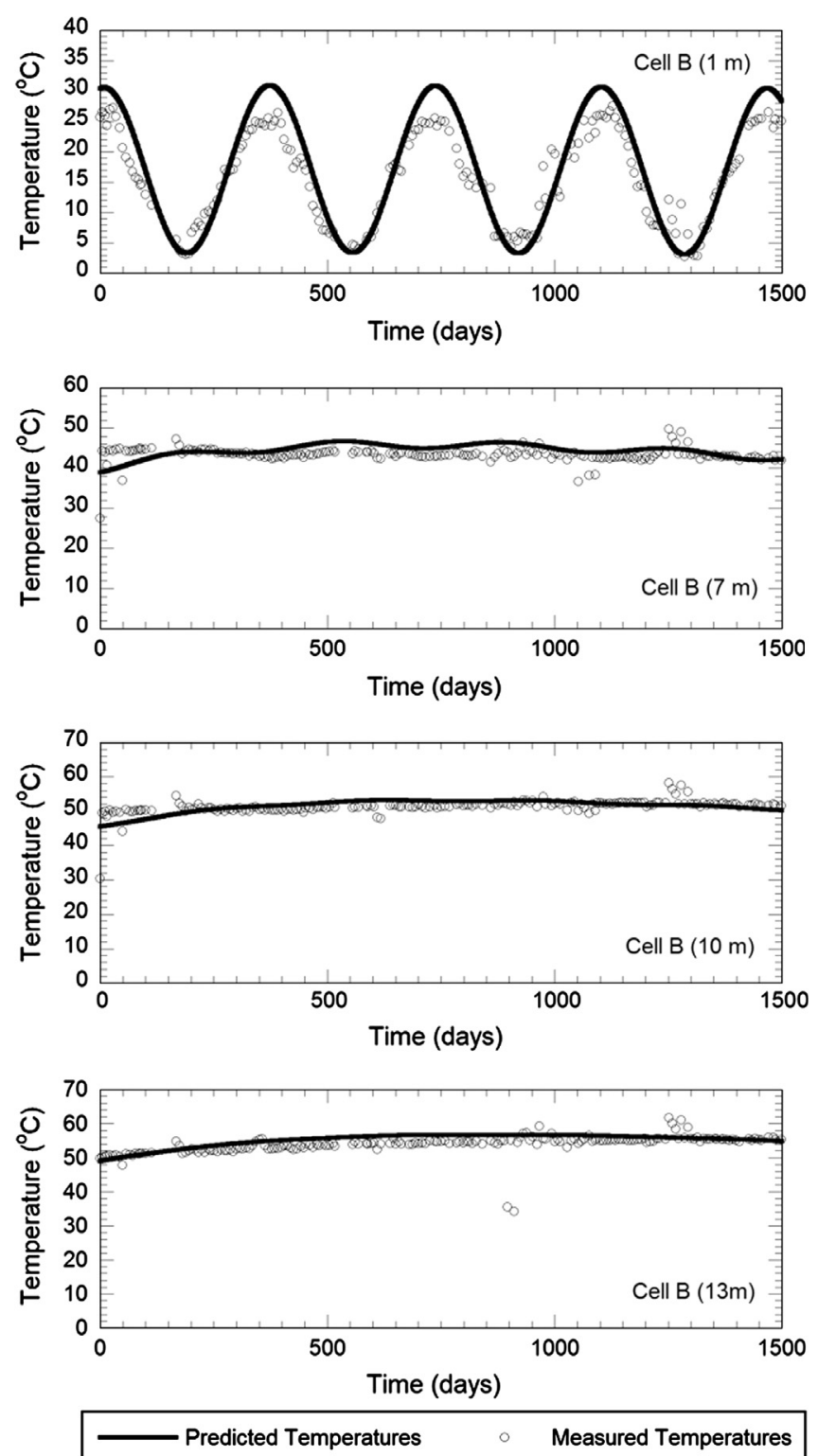

Fig. 8. Model performance for model validation in relatively old wastes at Cell B. the simulation envelope and for Cell B, $87 \%$ of the field data was contained within the simulation envelope. Approximately $74 \%$ and $94 \%$ of the field data were contained within envelopes extended $\pm 2{ }^{\circ} \mathrm{C}$ from the maximum and minimum envelopes presented in Fig. 9 for Cells B and D, respectively. The simulated and measured temperatures were higher at Cell B than at Cell D. Maximum simulated temperatures at central depths reached approximately $42^{\circ} \mathrm{C}$ for Cell D and approximately $56^{\circ} \mathrm{C}$ for Cell B.

The framework described in this paper can be used to predict heat generation and resulting temperatures in landfills. Such modeling provides for realistic thermal conditions for analysis of properties, response, and performance of waste containment facilities for mechanical stability as well as biochemical conditions. The energy expended based function is useful for less common operational and climatic conditions. Further analysis is underway to validate this approach.

\section{Conclusions}

Numerical modeling of temperatures in landfills requires transient, nonlinear analysis to account for complex boundary conditions and temporal trends. Heat generation rate functions of variable complexity were developed empirically that provided temporal trends in heat generation of wastes due to biological decomposition including: step function (aerobic/anaerobic), exponential growth/decay function, temperature-dependent exponential growth/decay function, and energy-expended-based function.

The temperature-dependent exponential-decay (i.e., timebased) formulation of heat generation for wastes was applied to a field site and analyzed. The peak heat generation rates were 1.52 and $1.16 \mathrm{~W} / \mathrm{m}^{3}$, the time for peak heat generation was 87 and 360 days, and total energy expended was 104 and $174 \mathrm{MJ} / \mathrm{m}^{3}$ for the baseline functions at Cells D and B at the site, respectively. The variability in heat generation functions resulted in different simulated temperature profiles for Cells D and B. The overall variability of temperatures was greater at Cell D with newer wastes than at Cell B with older wastes. Maximum simulated temperatures at central depths reached approximately $42^{\circ} \mathrm{C}$ for Cell D and approximately $56^{\circ} \mathrm{C}$ for Cell B. The model temperatures were within $\pm 2{ }^{\circ} \mathrm{C}$ to $\pm 5{ }^{\circ} \mathrm{C}$ of the measured temperatures. Thermal response including damping of seasonal temperature variations with depth, phase lag with depth, and onset and presence of heat gain due to waste decomposition were captured by the model.
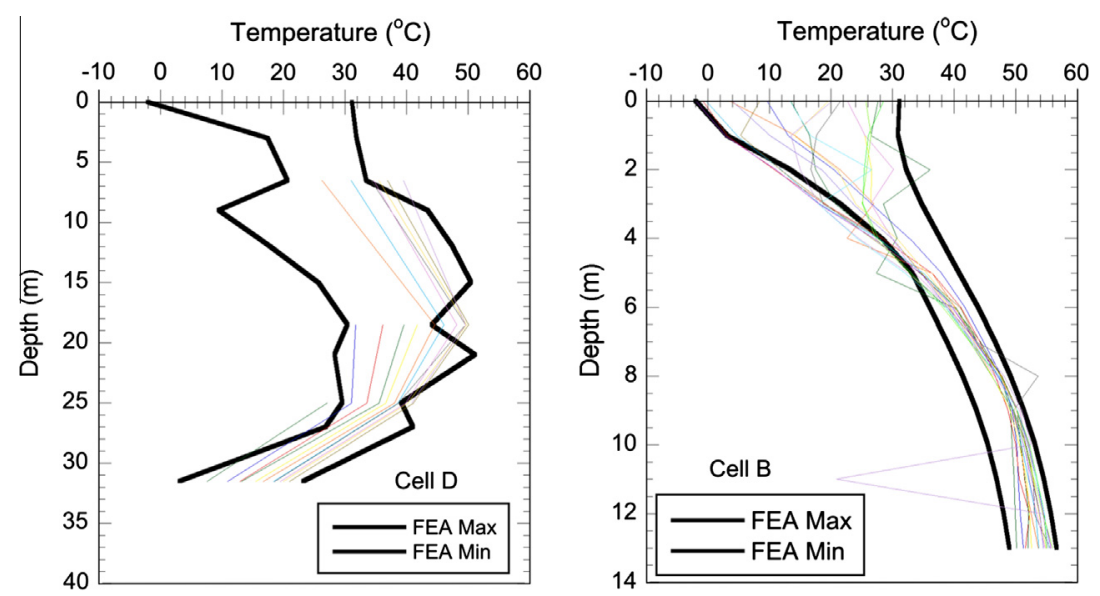

Fig. 9. Temperature versus depth profiles for Cells D and B. 
The model framework described herein can be used for developing formulations for prediction of temperatures within various components of landfill systems (liner, waste mass, cover, and surrounding subgrade), and determination of net heat gain due to decomposition of wastes. The numerical tool described in this paper can assist in providing realistic conditions for analysis of response and behavior of material components as well as response of overall systems for waste containment facilities.

\section{Acknowledgements}

This study was supported by the National Science Foundation (GOALI Grant: CMS-9813248, SGER Grant: CMS-0301032, and a 2004 AAAS/NSF WISC Grant). Assistance of partner landfills (Sauk Trail Hills Development, Corralitos Regional Landfill, Anchorage Regional Landfill, and Vancouver Landfill) and the Global Waste Research Institute is greatly appreciated.

\section{References}

Andersland, O.B., Ladanyi, B., 2003. Frozen Ground Engineering, second ed. Wiley, New York.

Carslaw, H.S., Jaeger, J.C., 1959. Conduction of Heat in Solids, second ed. Oxford University Press, Oxford.

Cook, D.R., Malkus, S.D., Plesha, E.M., Witt, R.J., 2002. Concepts and Applications of Finite Element Analysis, fourth ed. Wiley, NY.

Davies, T.W., 2004. Estimated average gross calorific values. Course SOE3154/55 Energy conversion. <http://www.ex.ac.uk/ TWDavies/energy_conversion/ calorific\%20values\%20of\%20fuels.htm> (last accessed 23.11.04).

Doll, P., 1997. Desiccation below mineral liners with heat production. J. Geotech. Geoenviron. Eng., ASCE 123 (11), 1001-1009.

El Fadel, M., Findikakis, A.N., Leckie, J.O., 1996. Numerical modelling of generation and transport of gas and heat in sanitary landfills: I. Model formulation. Waste Manage. Res. 14, 483-504.

Gibbs, A., 2004. Gasification as an option for municipal waste. Cardiff Foundation of Environmental Research, Cardiff University School of Engineering. <http:// www.cfer.info> (last accessed 16.11.04).

Hanson, J.L., Edil, T.B., Yeşiller, N., 2000. Thermal properties of high water content materials. In: Edil, T.B., Fox, P.J. (Eds.), ASTM Special Technical Publication 1374 Geotechnics of High Water Content Materials. ASTM, West Conshohocken, PA, pp. 137-151.

Hanson, J.L., Yeşiller, N., Kendall, L.A., 2005. Integrated temperature and gas analysis at a municipal solid waste landfill. Proceeding of the 16th International Conference on Soil Mechanics and Geotechnical Engineering, vol. 4. Millpress Science Publishers, Rotterdam, the Netherlands, pp. 2265-2268.

Hanson, J.L., Yeşiller, N., Howard, K.A., Liu, W.-L., Cooper, S.P., 2006. Effects of placement conditions on decomposition of municipal solid wastes in cold regions. In: Proceedings, 13th Annual Cold Regions Engineering Conference, ASCE, pp. 1-11.

Hanson, J.L., Liu, W.-L., Yeşiller, N., 2008. Analytical and numerical methodology for modeling temperatures in landfills. In: Khire et al. (Eds.), Proceedings of Selected Sessions of GeoCongress 08: Geotechnics of Waste Management and Remediation, ASCE GSP No. 177, ASCE, Reston, Virginia, pp. 24-31.

Hanson, J.L., Yeşiller, N., Oettle, N., 2010. Spatial and temporal temperature distributions in municipal solid waste landfills. J. Environ. Eng. 136 (8), 804814.
Hartz, K.E., Klink, R.E., Ham, R.K., 1982. Temperature effects: methane generation from landfill samples. J. Environ. Eng. 108 (EE4), 629-638.

Hoor, A., Rowe, R.K., 2011. Application of thermal insulation of landfill liners. In: Han, J., Alzamora, D.E. (Eds.), Proceedings, Geo-Frontiers 2011, ASCE 2011.

Lamothe, D., Edgers, L., 1994. The effects of environmental parameters on the laboratory compression of refuse. In: Proceedings, Seventeenth International Madison Waste Conference, Department of Engineering Professional Development, University of Wisconsin, Madison, Wisconsin, pp. 592-604.

Landsberg, H.E., Lippmann, H., Paffen, K.H., Troll, C., 1966. In: Rodenwaldt, E., Jusatz, H.J. (Eds.), World Maps of Climatology, third ed. Springer-Verlag, Berlin.

Lefebvre, X., Lanini, S., Houi, D., 2000. The role of aerobic activity on refuse temperature rise, I. Landfill experimental study. Waste Manage. Res. 18, 444452.

Liu, W.-L., 2007. Thermal Analysis of Landfills, Ph.D. Thesis, Wayne State University, Civil and Environmental Engineering Department, Detroit, Michigan.

McBean, E.A., Rovers, F.A., Farquhar, G.J., 1995. Solid Waste Landfill Engineering and Design. Prentice Hall, Englewood Cliffs, NJ.

Miller, P.A., Clesceri, N.L., 2003. Waste Sites as Biological Reactors: Characterization and Modeling. Lewis Publishers, CRC Press LLC.

Oettle, N.K., Hanson, J.L., and Yeşiller, N., 2008. Experimental determination of cover surface temperature functions at MSW landfills. In: Proceedings, 2008 Global Waste Management Symposium, Penton, Media. 1-7.

ORNL, 1981. Regional analysis of ground and above-ground climate. Oak Ridge National Laboratory Report No. ORNL/Sub-81/40451/1, U.S. Department of Energy, Office of Buildings Energy R\&D.

Pirt, S.J., 1978. Aerobic and anaerobic microbial digestion in waste reclamation. J. Appl. Chem. Biotechnol., Soc. Chem. Ind. 28, 232-236.

Rees, J.F., 1980. Optimisation of methane production and refuse decomposition in landfills by temperature control. J. Chem. Technol. Biotechnol. 30 (8), 458-465.

Rowe, R.K., 2005. Long-term performance of contaminant barrier systems, 45th Rankine Lecture. Geotechnique 55 (9), 631-678.

Rowe, R.K., Hoor, A., 2009. Predicted temperatures and service-lives of secondary geomembrane landfill liners. Geosynth. Int. 16 (2), 71-82.

SFOE, 2004. Calorific Value of Energy Resources. Swiss Federal Office of Energy <http://www.energieschweiz.ch/internet/00735/index.html?lang=en> (last accessed: 23.11.04)

Southen, J.M., Rowe, R.K., 2005. Modelling of thermally induced desiccation of geosynthetic clay liners. Geotext. Geomembr. 23 (5), 425-442.

Tchobanoglous, G., Theisen, H., Vigil, S.A., 1993. Integrated Solid Waste Management: Engineering Principles and Management Issues. McGraw Hill, Inc., New York, NY.

U.S. EPA, 2003. Municipal Solid Waste Generation, Recycling, and Disposal in the United States: Facts and Figures for 2003. United States Environmental Protection Agency, Washington, D.C.

Yeşiller, N., Hanson, J., Liu, W., 2005. Heat generation in municipal solid waste landfills. J. Geotech. Geoenviron. Eng., ASCE 131 (11), 1330-1344.

Yesiller, N., Hanson, J.L., Oettle, N.K., Liu, W.-L., 2008. Thermal analysis of cover systems in municipal solid waste landfills. J. Geotech. Geoenviron. Eng., ASCE 134 (11), 1655-1664.

Yoshida, H., Rowe, R.K., 2003. Consideration of landfill liner temperature. In: Christensen, T.H. et al., (Eds.), Proceedings, Sardinia 2003, Ninth International Waste Management and Landfill Symposium, CISA, Italy.

Yoshida, H., Tanaka, N., Hozumi, H., 1999. Theoretical study on temperature distribution in landfills by three-dimensional heat transport model. In: Christensen, T.H. et al. (Eds.), Proceedings, Sardinia 99, Seventh International Waste Management and Landfill Symposium, CISA, Cagliari, Italy.

Zanetti, M.C., Manna, L., Genon, G., 1997. Biogas production evaluation by means of thermal balances. In: Christensen, T.H. et al., (Eds.), Proceedings, Sardinia 1997, Sixth International Waste Management and Landfill Symposium, CISA, Italy, vol. II, pp. 523-531 